\title{
Renal Primitive Neuroectodermal Tumor
}

\author{
Böbrek Primitif Nöroektodermal Tümörü
}

\author{
Hüseyin Çelik', Ahmet Camtosun', İbrahim Dursun'2, Nusret Akpolat', İsmail Okan Yıldırım \\ 'Inönü University Faculty of Medicine, Department of Urology, Malatya, Turkiye \\ ${ }^{2}$ Inönü University Faculty of Medicine, Department of Medical Oncology, Malatya, Turkiye \\ ${ }^{3}$ Inönü University Faculty of Medicine, Department of Pathology, Malatya, Turkiye \\ ${ }^{4}$ Inönü University Faculty of Medicine, Department of Radiology, Malatya, Turkiye
}

\begin{abstract}
Renal primitive neuroectodermal tumor (PNET) is a rare entity and highly malignant neoplasm. It generally occurs in young adults and children. We report a case of 19-year-old female with the complaint of left flank pain. Ultrasonography showed a tumor of the left kidney. A big left inhomogeneous renal mass of 10x8 cm with areas of necrosis was observed on computed tomography. The patient underwent radical nephrectomy with lymphadenectomy. Immunohistochemical stains were positive for CD99 and FL-1. Immunohistochemical and microscopic results were compatible with PNET. Furthermore, the patient received eight cycles of chemotherapy, and was still alive without metastases at 6-month followup. Renal PNET is a rare and poor prognosis tumor. It is sometimes difficult to discriminate between PNET and Ewing's sarcoma. Renal PNET must be included in the differential diagnosis of renal tumors particularly in young adults and children. With this case report it aimed to create awareness about PNET.
\end{abstract}

Keywords: Primitive neuroectodermal tumor, kidney, Ewing's sarcoma

\section{Öz}

Böbreğin primitif nöroektodermal tümörleri (PNET) oldukça nadir görülen ve ileri derecede malign neoplazilerdir. Genellikle çocuk ve genç erişkinlerde görülür. Biz 19 yaşında sol yan ağrısı ile kliniğimize başvuran bir kadın hastayı sunduk. Ultrasonografi sol böbrekte kitle tespit etti. Bilgisayarlı tomografisinde sol tarafta 10x8 cm boyutlarında heterojen, nekrotik alanlar içeren kitle görüldü. Hastaya radikal nefrektomi ve lenfadenektomi yapıldı. İmmünohistokimyasal olarak CD99 ve FL-1 ile pozitif boyandı. Mikroskobik ve immünohistokimyasal olarak PNET tanısı konuldu. Sonrasında hastaya 8 kür kemoterapi verildi, şu ana kadarki 6 aylık takibinde metastaz izlenmedi. Renal PNET nadir görülen ve kötü prognozlu bir tümördür, bazen Ewing sarkom ile ayrımı güç olmaktadır. Özellikle çocuklarda ve genç erişkinlerde renal tümörlerin ayırıcı tanısında PNET düşünülmelidir. Bu olgu sunumu ile tümör hakkında bir farkındalık oluşturulması amaçlanmıştır.

Anahtar Kelimeler: Primitif nöroektodermal tümör, böbrek, Ewing sarkom

\section{Introduction}

Primitive neuroectodermal tumor (PNET) is presumed to result from primitive neural crest cells and mostly involves the bone or soft tissue in children and young adults (1). PNET and Ewing's sarcoma are considered almost the same entity because of the morphological and genetic similarities (2). Renal PNET is a rare condition having an aggressive clinical course towards metastatic disease and death. The median decade for renal PNET is second decade but it can be seen also in a wide age range between 3 and 78 years (3). It recurs locally and spreads to regional lymph nodes, lungs, liver, bone and bone marrow at an early disease stage (4). Prognosis seems to be better in younger patients, however, the 5 -year disease-free survival rate is around $45-55 \%$ (5). We present a rare case of a 19-year-old female with renal PNET and a review of the literature.

\section{Case Presentation}

A 19-year-old female with the complaint of left flank pain for 1 week was admitted. Physical examination revealed a non-tender abdomen with fullness in the left upper quadrant. Laboratory evaluation, including complete blood count was normal.

Correspondence: Hüseyin Çelik MD, İnönü University Faculty of Medicine, Department of Urology, Malatya, Turkiye

Phone: +90 4223410660 E-mail: drhuseyin@hotmail.com

Received: 27.11.2015 Accepted: 22.04.2016

Cite this article as: Çelik H, Camtosun A, Dursun I, Akpolat N, Yıldırım iO. Renal Primitive Neuroectodermal Tumor. J Urol Surg 2017;4:82-84.

๑Copyright 2017 by the Association of Urological Surgery / Journal of Urological Surgery published by Galenos Publishing House. 
Ultrasonography identified a left renal mass homogeneously hyperechogenic in comparison with renal parenchyma. Computed tomography scan showed a 10x8 $\mathrm{cm}$ substantive tumor involving the upper pole of the left kidney, while in the enhanced phase, the tumor presented inhomogeneous contrast enhancement with necrotic areas (Figure 1). Chest X-ray was negative.

The patient underwent left radical nephrectomy and retroperitoneal lymphadenectomy. Pathological analysis revealed a $13 \times 8 \times 5 \mathrm{~cm}$ tumor involving the entire left kidney, including Gerota's fascia, and negative surgical margins. The renal vein, ureter and lymph nodes were negative for malignancy. Histological examination revealed small circular undifferentiated tumoral cells with scarce cytoplasm, oval to round hyperchromatic nuclei. The tumor had massive areas of necrosis without tubule or rosette formation (Figure 2). Immunohistochemistry revealed that tumor cells were strongly positive for MIC2 (CD99) as well as PanCK, CD56, CD57 and FL-1 (Figure 2). The tumor cells were negative for CK7, CK20, thrombomodulin, vimentin, neuron-specific enolase (NSE) and CD117. Based upon the immunohistochemical features and microscopic appearance, the diagnosis of PNET of the kidney was established. The pathologic stage of the tumor was pT3a. Eight cycles of chemotherapy with vincristine, ifosfamide and adriamycin, four cycles of ifosfamide and (etoposide) VP16 were sequentially performed and she was still alive without metastases at the 6-month follow-up.

\section{Discussion}

PNETs are small round cell tumors originating from cells of the primitive ectoderm and comprise 1\% of all sarcomas (1). Renal PNET is rare entity and has aggressive behavior. It frequently occurs during childhood or adolescence, having an aggressive clinical course towards metastatic disease and death (6). The most common symptoms in renal PNET are flank pain (67.5\%), hematuria (33.8\%) and mass (33.8\%). There is no relationship between the clinical manifestation and survival that is between the clinical signs and age (7). The mean survival is about 10 months. One patient was alive without evidence of disease with a survival of 64 months which seems to be the longest survival in the literature (5).

Renal PNET is diagnosed with pathological findings. Although Homer-Wright rosettes can be found also in neuroblastoma, these formations are the histologic hallmarks of PNET. Immunohistochemically, MIC2 (CD99), NSE, vimentin, synaptophysin and S-100 are expressed by PNET cells. The immune marker CD99 is present in virtually all tumors (8). However, CD99 is not specific and cannot be used as an absolute biomarker. The distinction from Wilms' tumor may be difficult, for Wilms' tumor may sometimes be positive for CD99. Nuclear protein FL-1 and WT- 1 have been described in renal PNETs by Jimenez et al. (5). They observed FL-1 expression in 63\% of PNETs, however it has not been found in Wilms' tumors. On the other hand, they did not view expression of WT-1 in renal PNETs whereas

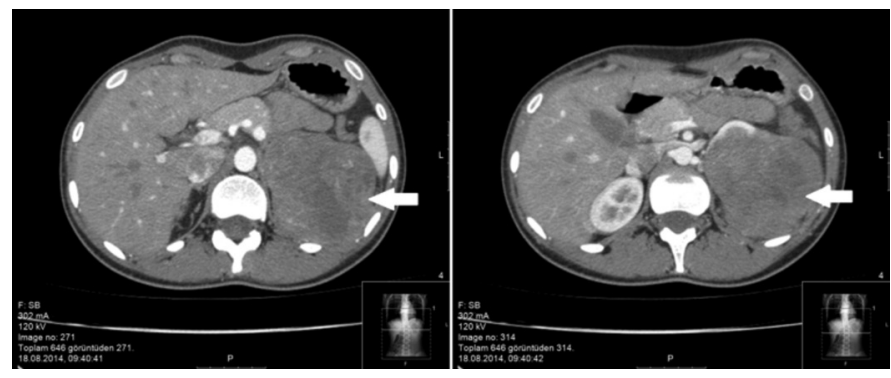

Figure 1. Computed tomography scan of the kidney demonstrated a 10x8 cm substantive tumor involving the upper pole of the left kidney

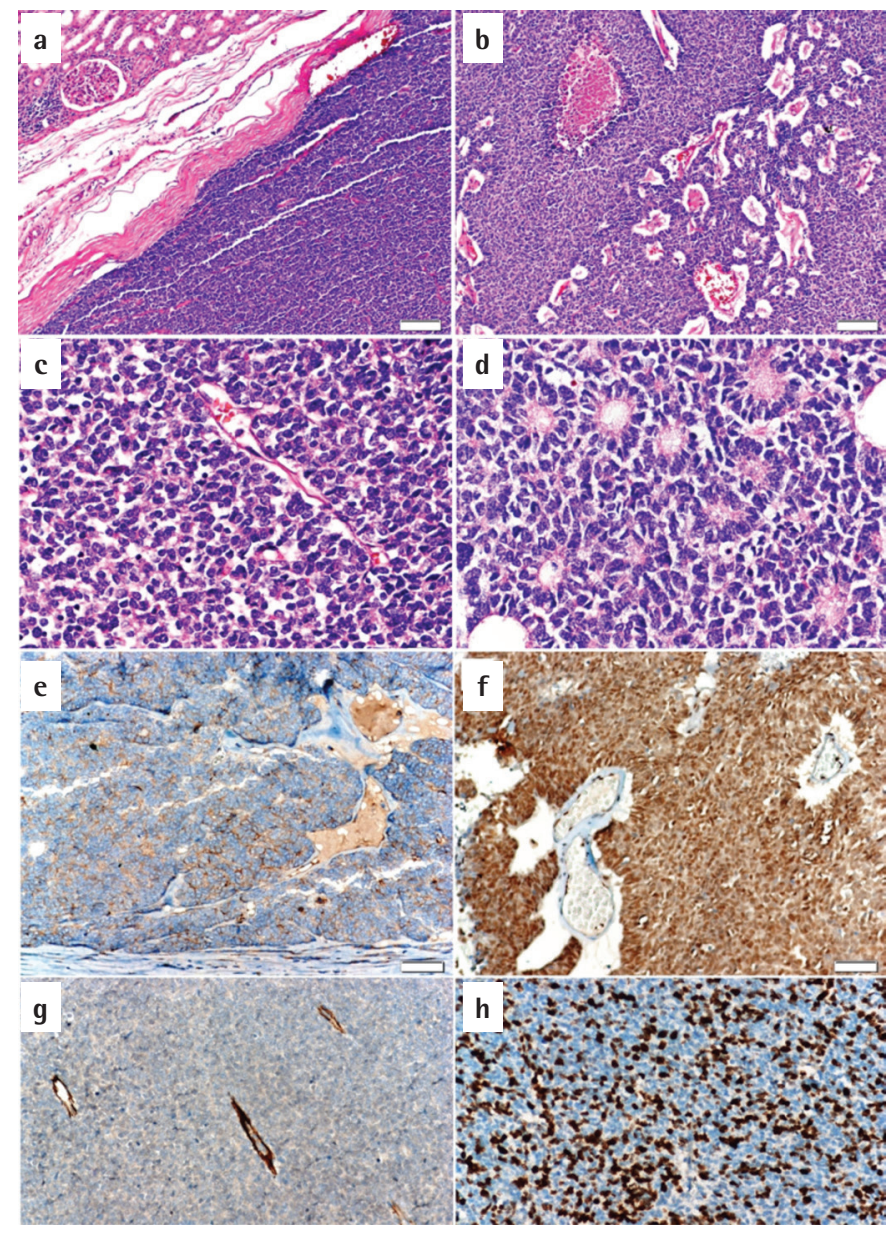

Figure 2. a) There is a thick capsule of the tumor is removed by the kidney with a sharp boundary (hematoxylin and eosin, x100), b) Neoplastic cells at the bottom right, shows perivascular pseudorosette formation and the upper left central necrosis and peripheral polizating (hematoxylin and eosin, $\mathrm{x} 100), \mathrm{c})$ Neoplastic cells is greater magnification and narrow oval, round core coarse heterogeneous cytoplasm shows diffuse chromatin pattern (hematoxylin and eosin, x400), d) Tumor cells form Homer-Wright type rosettes, e) VT-1 negative expression, f) FL-1 diffuse nuclear positivity, g) CD99 diffuse cytoplasmic positivity, h) High positive Ki67 index (70\%) 
in 78\% of Wilms' tumors. In this case, immunohistochemical stains were positive for CD99, PanCK, CD56, CD57 and FL-1 whereas negative for CK7, CK20, P63, WT-1, MACR, vimentin, thrombomodulin, synaptophysin, NSE, CRG and CD117. Both the pathological characteristics and the positive expression of CD99 and FL-1 as well as negative expression of WT- 1 in the tumor cells could support the diagnosis of renal PNET.

The most common genetic mutation in PNETs is $\mathrm{t}(11 ; 22)(\mathrm{q} 24 ; \mathrm{q} 12)$ and the erythroblast transformation-specific-related oncogene (11q24) has been detected in more than 90\% of renal PNETs (9). Molecular testing is useful in situations with a confusing immunohistochemical profile. The diagnosis of renal PNET always needs to include tumor morphology, immunostaining profile and sometimes genetic mutations (10).

Renal PNET is a rare neoplasm with a poor prognosis and should be differentiated from other small cell tumors of the kidney. Specific histological features, immunostaining profile and genetic features must be considered in making the histologic diagnosis. Especially, immunohistochemical staining for CD99 and FL-1 with cytogenetic studies plays a great role in the diagnosis of renal PNET. In addition, multidisciplinary approach is essential in the management of renal PNET.

\section{Ethics}

Informed Consent: Written informed consent was obtained from the parents of the patient.

Peer-review: Externally peer-reviewed.

\section{Authorship Contributions}

Surgical and Medical Practices: H.Ç., A.C., Concept: H.Ç., I.D., Design: H.Ç., N.A., Data Collection or Processing: H.Ç., Analysis or Interpretation: N.A., I.O.Y., Literature Search: H.Ç., A.C., Writing: H.Ç., N.A.
Conflict of Interest: No conflict of interest was declared by the authors.

Financial Disclosure: The authors declared that this study received no financial support.

\section{References}

1. Rodriguez C, Marina N, Fletcher B, Parham D, Bodner S, Meyer W. Is primitive neuroectodermal tumor of the kidney a distinct entity? Cancer $1997 ; 79: 2243-2250$

2. Salgado C, Neff T, Frazier L, Vargas SO, Veen DV. An unusual case of congenital primitive neuroectodermal tumor with ocular metastasis. J Pediatr Hematol Oncol 2012;34:69-71.

3. Koski ME, Tedesco JM, Clark PE. Renal peripheral neuroectodermal tumor presenting at age 78: case report. ScientificWorldJournal 2008;8:830-834.

4. Casella R, Moch H, Rochlitz C, Meier V, Seifert B, Mihatsch MJ, Gasser TC Metastatic primitive neuroectodermal tumor of the kidney in adults. Eur Urol 2001;39:613-617.

5. Jimenez RE, Folpe $A L$, Lapham RL, Ro JY, O'Shea PA, Weiss SW, Amin MB Primary Ewing's sarcoma/primitive neuroectodermal tumor of the kidney: a clinicopathologic and immunohistochemical analysis of 11 cases. Am J Surg Pathol 2002;26:320-327.

6. Pomara G, Cappello F, Cuttano MG, Rappa F, Morelli G, Mancini P, Selli C. Primitive Neuroectodermal Tumor (PNET) of the kidney: a case report. BMC Cancer 2004;4:3.

7. Aghili M, Rafiei $E$, Mojahed M, Zare M. Renal primitive neuroectodermal tumor: does age at diagnosis impact outcomes? Rare Tumors 2012;4:e15.

8. Ellinger J, Bastian PJ, Hauser S, Biermann K, Müller SC. Primitive neuroectodermal tumor: Rare, highly aggressive differential diagnosis in urologic malignancies. Urology 2006;68:257-262.

9. Wu Y, Zhu Y, Chen H, Huang Y, Wei Q, Chen HJ, Xie X, Li X, Zhou Q, Yang YR Zeng $\mathrm{H}$. Primitive neuroectodermal tumor of the kidney with inferior vena cava tumor thrombus during pregnancy response to sorafenib. Chin Med J 2010;123:2155-2158.

10. Sun C, Du Z, Tong S, Xu K, Ding W, Sun J, Ding O. Primitive neuroectodermal tumor of the kidney: case report and review of literature. World J Surg Oncol 2012;27;10:279. 